\title{
Building for Life: \\ A Recent British Attempt to Raise the Quality of Housing
}

\section{Ivor Samuels}

Architect; Honorary Senior Research Fellow, Urban Morphology Research Group, Dept of Geography, Birmingham University; Tutor, Oxford University's Continuing Education. Visiting Lecturer in CRP, Spring Quarter of 2006 and 2007.

In Britain, there has been a recent effort by the government in partnership with the building industry to set national standards for good quality housing, not unlike the LEED system in the US. Noting how housing is always a political issue and the undeniable need to encourage its quality, Ivor Samuels discusses this attempt, its influence in subsidized housing, and some it is shortfalls.

A n attempt to systemise the delivery of better quality housing has recently been occurring in England. As well as shelter being one of the most fundamental of human needs, in land use terms housing occupies the greatest part of our towns-so it has an enormous impact on the quality of the urban environment. Housing is always a major political issue, as will be briefly touched on below, and it is fundamental to our economies as The Guardian newspaper of 26 November 2008 observed:

"This financial crisis began with housing, and any hope of its ending must lie with housing."

Yet it is arguable that the design of housing is one of the most neglected fields of professional endeavor for architects. Those "starchitects" who dominate the pages of the architectural journals, the Hadids and Fosters, very rarely venture into the field of housing. If they do, it is to execute exceptional schemes like Richard Rogers' recent Hyde Park flats in London, where one apartment is reported to have been sold to a Russian oligarch for 223 million dollars ${ }^{1}$. The same situation no doubt pertains in the US.

While these architects are, for the main part, modernists, their neglect of housing represents a betrayal of the Modern Movement, which was born out of aspiration to provide good housing for the masses of the industrial revolutionfirst of all through Garden Cities and then the post war New Towns and housing estates. This neglect, and some notable failures of modernist housing schemes (Britain has its own Pruit lgoes) have left the field free for the New Urbanists and the practitioners of the neo-vernacular style. Poundbury is the prime British example of this style, but it has also been enthusiastically taken up in a degraded form by the volume house-builders-with depressing results (Figures $1 \& 2$ ).

This neglect of housing starts in our architectural schools. In

${ }^{1}$ See <http://www.onehydepark.com/media-centre>; access on 06/12/2013. the ABAG wesite at < http://www.abag.ca.gov/> the last school where this author taught, one of the largest in the UK, it was possible to go through a five-year studio-based training without ever designing housing, as opposed to single special houses - the legendary house for a musician on a cliff-top may be an exaggeration, but is not far off the sort of projects offered. As this paper was being written, the following appeared from Maritz Van den Berg, former technical editor of the Architectural Press in the Building Design, the most widely read architects' weekly:

"...current teaching lavishes attention on standalone icons, experimental designs or whimsical fantasies. On planet earth meanwhile volume house builders will soon be designing the 5,000,000 or more new dwellings projected to be built in England over the next decade. They will be doing this with little helpful input from young architects, whose training never gave any sustained attention to affordable mass housing of a kind that will appeal to buyers. And if these streets and neighbourhoods turn out to be mediocre or worse, the blame will be placed on everyone except the true culprits-the heads of our schools of architecture" (Vandenberg, 2013: 7.)

Figure 1: The fashion for neovernacular style can be an excuse for poor quality housing - it is cheaper to provide small windows.

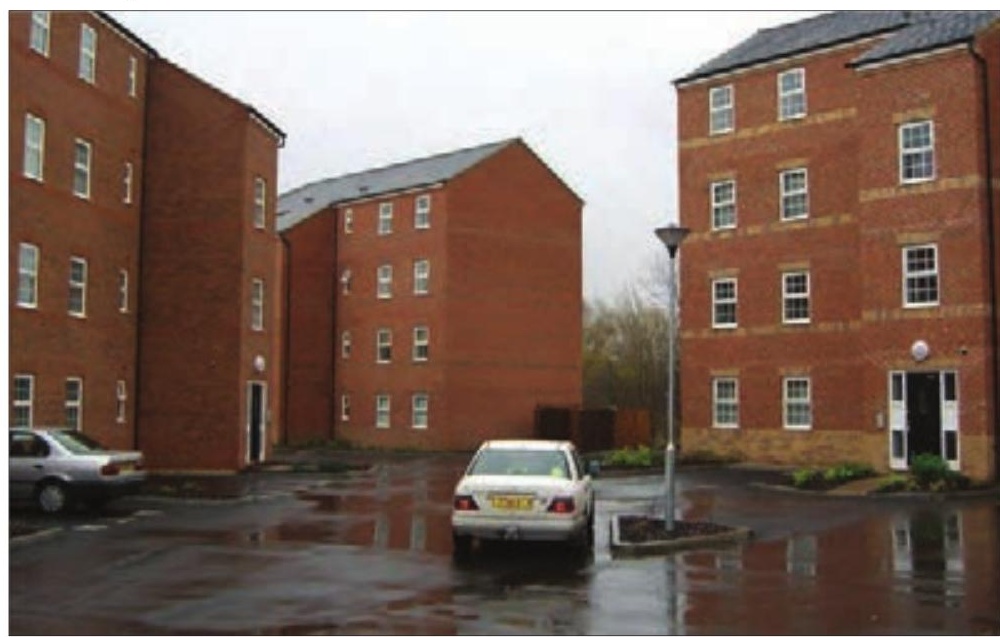




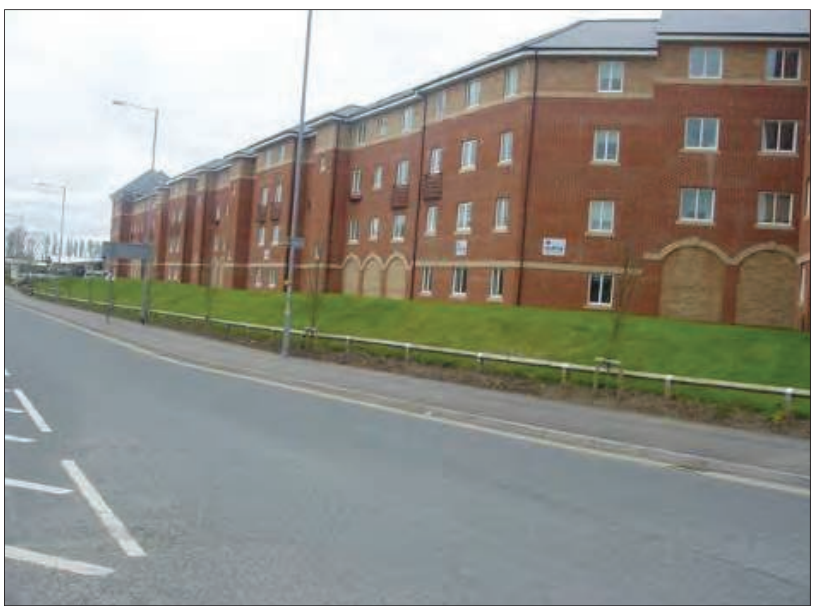

Figure 2: Another neovernacular housing scheme with depressing results and low urban design quality.

The role of planning through the relevant, according to the context, system of plans, codes, and the granting of permits is therefore of fundamental importance for achieving quality in new housing developments. However, the urban design capacity of planners varies, and with cutbacks in planning departments under the austerity regime in the UK at present it is precisely this design capacity of planning departments which is being reduced. Priority and therefore resources are being given to the statutory development control functions, which are often performed by planning officers who have limited urban design skills but who are proficient in the legal aspects of the planning system.

\section{The Commission for Built Environment (CABE) and Building for Life (BfL)}

From 1999 to 2011 CABE was the British government's advisor on architecture, urban design and public space. It undertook studies and published an impressive range of advice on topics such as design review, urban design coding, design rationales and strategic urban design and it seconded advisors to local authorities for specific projects under a programme which was called enabling. That activity is now history since CABE was emasculated by the new government in 2011 and in a greatly reduced size became part of the Design Council where it would no longer receive government subsidy but become self funded through design review activity. ${ }^{2}$

In 2001 CABE launched Building for Life in partnership with the building industry through the House Builders Federation and the Civic Trust (CABE 2001) It was promoted as providing the national standard for well designed homes and neighbourhoods. In its own words:

\footnotetext{
${ }^{2}$ CABE's publications are still relevant and can be found in the national archives at: http://webarchive.nationalarchives.gov.uk/ 20110118095356/http://www.cabe.org.uk/timeline
}

"Good quality housing design can improve social wellbeing and quality of life by reducing crime, improving public health, easing transport problems and increasing property values. Building for Life promotes design excellence and celebrates best practice in the house building industry." (CABE, 2001: 6)

It celebrated best practice in housing by making annual awards and from 2009, for a short period until the government changed in 2010, all local authorities were required to assess schemes over 10 units according to Building for Life criteria and include the results in their annual monitoring reports.

For the evaluations, which were undertaken by CABE's own assessors or those trained by CABE through a programme of workshops, twenty criteria were proposed. These were based on widely accepted urban design principles such as those set out in government publications such as By Design: Urban Design in the Planning System Towards Better Practice (DETR 2000).

Projects, whether implemented or in the design stage, were interrogated and scored according to the following twenty questions which were grouped under four headings. Each question could be awarded 1 point although later this was modified to enable the award of 0.5 points to schemes which partially satisfied one of the criteria. Thus the maximum award could be $20 / 20$. The questions were:

\section{Environment and community}

1. Does the development provide (or is it close to) community facilities, such as a school, parks, play areas, shops, pubs or cafes?

2. Is there an accommodation mix that reflects the needs and aspirations of the local community?

3. Is there a tenure mix that reflects the needs of the local community?

4. Does the development have easy access to public transport?

5. Does the development have any features that reduce its environmental impact?

\section{Character}

6. Is the design specific to the scheme?

7. Does the scheme exploit existing buildings, landscape or topography?

8. Does the scheme feel like a place with distinctive character?

9. Do the buildings and layout make it easy to find your way around?

10. Are streets defined by a well-structured building layout?

Streets, parking and pedestrianisation

11. Does the building layout take priority over the streets and car parking, so that the highways do not dominate? 
12. Is the car parking well integrated and situated so it supports the street scene?

13. Are the streets pedestrian, cycle and vehicle friendly?

14. Does the scheme integrate with existing streets, paths and surrounding development?

15. Are public spaces and pedestrian routes overlooked and do they feel safe?

\section{Design and construction}

16. Is public space well designed and does it have suitable management arrangements in place?

17. Do the buildings exhibit architectural quality?

18. Do internal spaces and layout allow for adaptation, conversion or extension?

19. Has the scheme made use of advances in construction or technology that enhance its performance, quality and attractiveness?

20. Do buildings or spaces outperform statutory minima, such as building regulations?

Certainly there are a number of ambiguities or repetitions in the above questions. For example, there is an overlap between criteria 10 and 11 that treat the relation between built form and the public space system and some criteria, such as 17 dealing with architectural quality, could be considered as subjective. However if the assessor has to give justification for the assessment, then the danger of subjectivity, if not removed, is considerably reduced.

A worked example of the evaluation of an implemented housing scheme is given in Appendix 1. With a score of 14.5/20 it was a highly rated project capable of being given an award. Whatever the criticisms that can be levelled at the criteria they did give basis for making a comparison between built schemes and a rational for rejecting proposals of poor quality. CABE used this opportunity to undertake regional housing quality audits. These had a great potential to measure the change, over time, in housing quality.

The diagram represented in Figure 2 allows the comparison of two housing quality audits carried out in 2005 and shows the difference between the affluent South of England and the North - the English equivalent of the rust belt. While nearly $94 \%$ in the North are average or poor as against $83 \%$ in these categories in the South, there are only $6 \%$ good or very good $n$ the north as against $17 \%$ in these two categories in the south.

\section{Kickstart and Building for Life}

In 2009, in the depths of the financial crisis, the then Labour government introduced a programme of public subsidy in attempt to get the housing market moving again. The Kickstart Housing Delivery Programme gave government subsidies to housing schemes which had stalled because of financial difficulties. The requirements were that they should

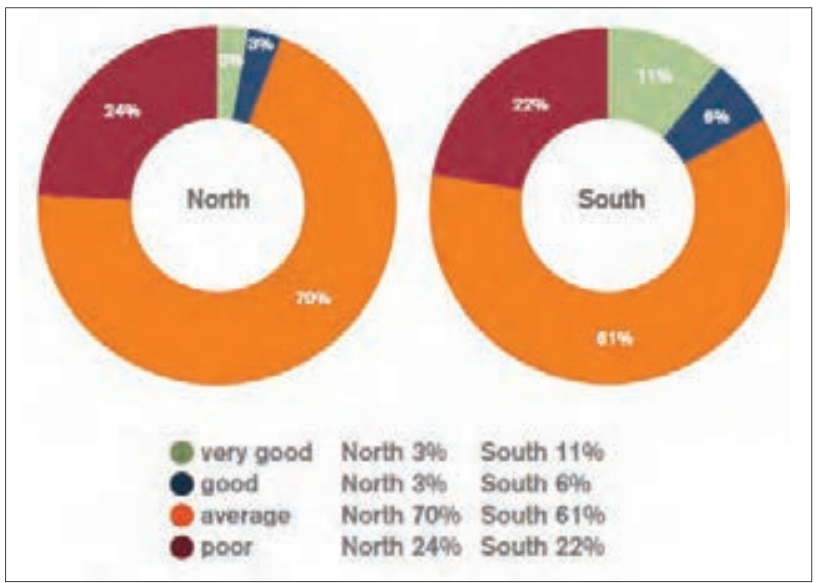

Figure 3: A comparison of housing quality in two English regions. (Source, CABE 2010: 10)

be a minimum of fifty units, meet locally identified needs and priorities, be completed by March 20011, and most important for the argument of this paper, have received detailed planning permission by September 2009. In the first round a total of 156 units were approved, twenty of which were conditional approvals subject to revision.

The first disclosure of selected projects caused an uproar because of the poor quality of some of the schemes, to the extent that questions were asked in the Houses of Parliament. It must be noted that they had all been passed by the local planning authorities although not necessarily subject to a BfL evaluation.

The Homes and Communities agency review of the first phase of Kickstart (HACA 2009 gives an indication of the scores achieved but it does not identify specific schemes because of "commercial sensitivity"). The average BfL score on approved schemes was 9.3. The groupings are as follows:

- 16/20 or more: 11 schemes

- 14 to $16 / 20: 12$ schemes

- 12 to 14/20: 19 schemes

- 9 to 12/20: 27 schemes

- Less than 9/20: 67 schemes

This officially published information shows that nearly half the schemes approved for funding scored less than 9/20. It does not reveal just how bad some approved for design schemes were. It was only after a cross party group of Members of Parliament had demanded more details. The weekly Building Design (Hurst, W. 2010) revealed that twenty-seven of the funded projects had scored $5 / 20$ or less with two projects achieving only 1.5/20 (Figures 4, 5 and 6).

\section{A Political Postscript}

It has already been noted that CABE was virtually abolished by the new coalition government that came into power in 2010. 


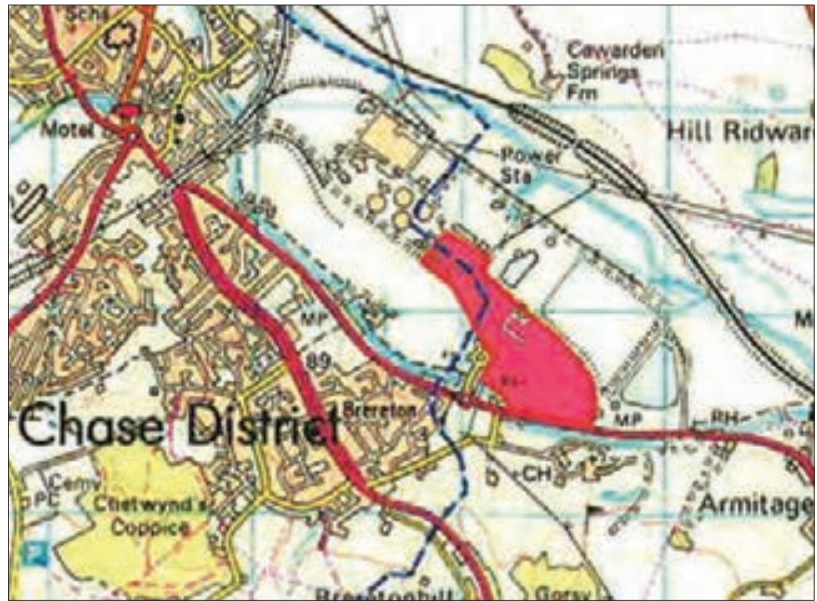

Figure 4: A Kickstart proposal (in red) for a new housing area with no pedestrian or cycle connection, except via a high speed traffic highway, to the local settlement and its facilities. (Author's archive)

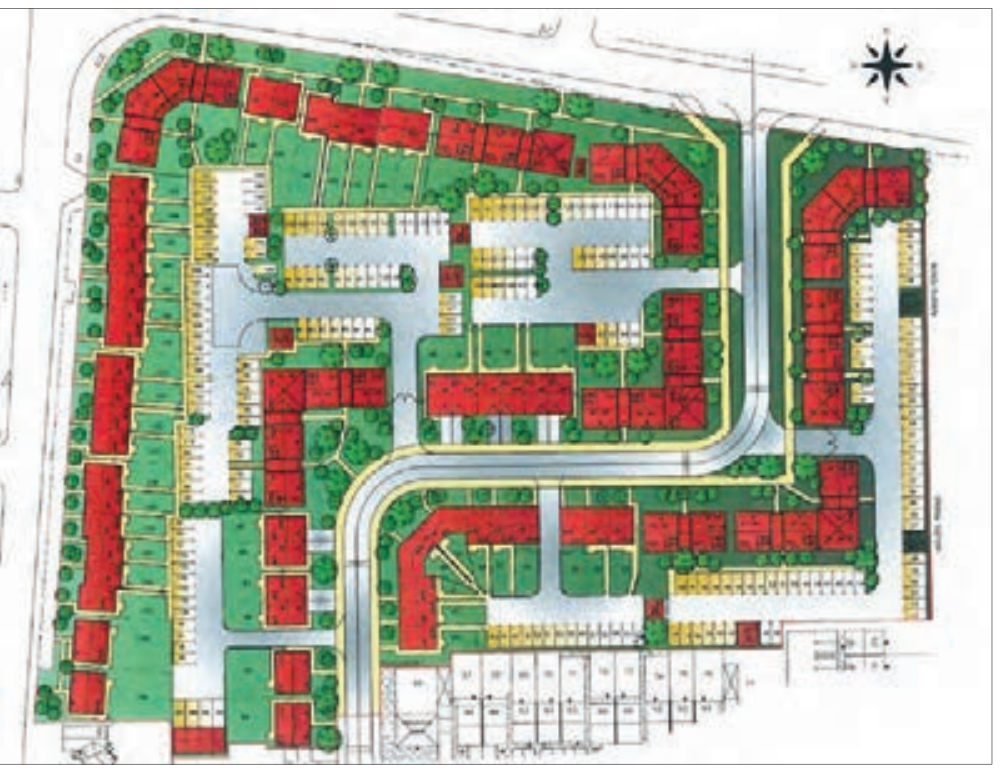

Figure 5: Plan of a Kickstart project that was evaluated with BfL and scored 1.5/20 BfL. Although the scheme was defective in many ways, this shows the large open parking areas which are notoriously insecure. (Author's archive)

This government claimed that the whole planning system was a hindrance to economic recovery after the worst recession since the 1930s development and to a resolution of the crisis in housing in particular. The whole town planning profession became a useful scapegoat for the nation's inability to resume economic growth. The previous planning system was ditched and with it all attempts to plan rationally the city regions across which most people live their lives in favour of what was termed localisms. This author has previously commented on these policies in Focus ( Samuels 2012).

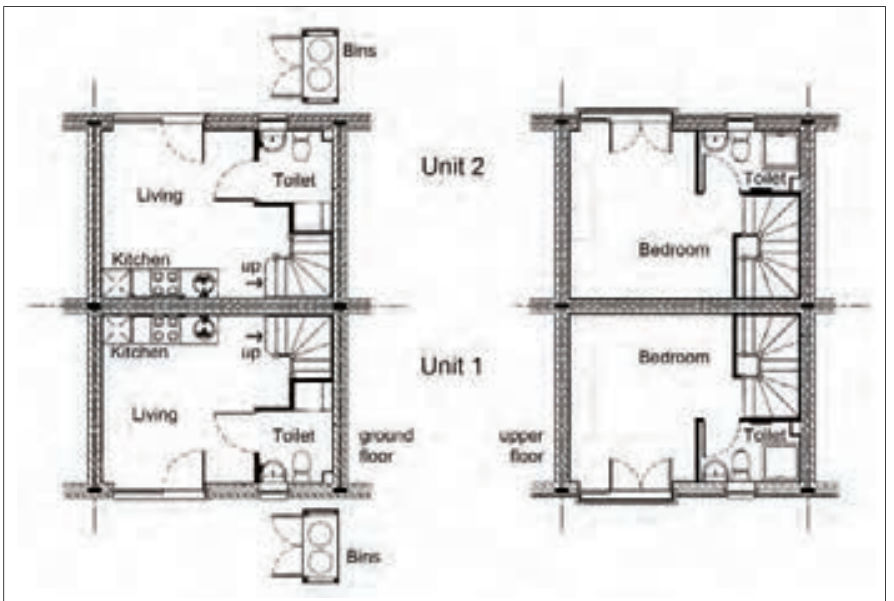

Figure 6: Kickstart single bedroom two story back to back houses, each with one external wall, which scored 4/20 BfL. This project seeks to revive a form of housing associated with the nineteenth century industrial revolution. (Author's archive)

Building for Life became one victim of this systematic process of deregulation. The house builders re-established their involvement through the agency of Design for Homes, a small organisation which had been involved initially in the establishment of Building for Life but whose influence had been minimised by the contribution of CABE with its greater resources and influence.

A new Building for Life set of criteria entitled BfL 12 was devised (Birkbeck et al, 2012). This certainly has removed some of the ambiguities and duplications in the earlier scheme and instead of points new and proposed projects will be awarded green, amber or red lights:

"Schemes that are considered to have achieved 12 'greens' will be eligible for 'Building for Life Diamond' status as exemplars" (Birkbeck et al 2012, p.3)

The major change however is the omission of any opportunity to comment on the internal arrangements of the dwellings, the introduction of modern methods of construction and the use of measures which can reduce the environmental impact of a development. The first omission is particularly important since new British homes have consistently been much smaller than those in other European countries - not to mention the US where space standards are so much more generous (Table 1).

This is borne out by the following table taken from a publication of the right wing free market think tank The Policy Exchange -certainly no advocate of greater regulation. Note that the average new British house is only half the area of the average new Danish house and that Britain is one of the few countries where new house sizes are smaller than the average of all dwellings - one reason why we prefer old houses with all their disadvantages of high maintenance costs and poor energy performance (Samuels, 2004). 
Table 1: A comparison of dwelling sizes in fifteen

European countries (Evans and Hartwich, 2005)

\begin{tabular}{|c|c|c|c|c|c|c|}
\hline \multirow{2}{*}{\multicolumn{7}{|c|}{$\begin{array}{l}\text { A. floor space }\left(\mathrm{m}^{2}\right) \\
\text { B. number of rooms } \\
\text { C. room size }\left(\mathrm{m}^{2}\right)\end{array}$}} \\
\hline & & & & & & \\
\hline & \multicolumn{3}{|c|}{ All dwellings } & \multicolumn{3}{|c|}{ Newly built dwelling } \\
\hline & A & B & c & A & B & c \\
\hline UK & 85 & 52 & 163 & 76 & 48 & 15.8 \\
\hline traly & 903 & 4.1 & 22 & 815 & 3.8 & 21.4 \\
\hline Portugal & 83 & 43 & 193 & 822 & 47 & 175 \\
\hline Swed en & 89.8 & 43 & 20.9 & 83 & 4 & 208 \\
\hline Finland & 765 & 3.6 & 213 & 87.1 & 4 & 21.8 \\
\hline lrekand & 883 & 53 & 16.7 & 877 & 52 & 169 \\
\hline Austria & 90.6 & 34 & 26.6 & 96 & 3.7 & 25.9 \\
\hline Spain & 85.3 & 48 & 178 & 96.6 & 51 & 18.9 \\
\hline Luxemburg & 125 & 5.5 & 227 & 104.1 & 51 & 204 \\
\hline Germany & 867 & 4.4 & 19.7 & 1092 & 5.1 & 21.4 \\
\hline France & 88 & 3.9 & 226 & 1128 & 42 & 26.9 \\
\hline Netherlands & 98 & 42 & 233 & 115.5 & 41 & 28.2 \\
\hline Belgium & 863 & 43 & 201 & 119 & 5.8 & 205 \\
\hline Greece & 79.6 & 3.8 & 20.9 & 126.4 & 32 & 39.5 \\
\hline Denmark & 1089 & 37 & 29.4 & 137 & 3,5 & 391 \\
\hline
\end{tabular}

Worst of all, this new system removes the opportunity to measure the improvement or the deterioration of housing standards over time. Because a different scheme of evaluation is being implemented it renders the considerable amount of data previously acquired on projects useless for comparative purposes. It is thus very easy for house builders to obscure any reduction in quality and standards even though they may switch on lots of green lights.

\section{References}

Birkbeck, D. Kruczowski, S. Colins, P. Quinn, B. 2012. The sign of a good place to live. Building for Life 12. London: Building for Life Partnership. (Available at http://www.hbf. co.uk/uploads/media/BfL_A4_booklet_singlepages_.pdf. Accessed 8/6 /2013)

CABE - Commission for Architecture and the Built Environment. 2001). Building for Life. London. (Available at http://webarchive.nationalarchives.gov. uk/20110118095356/http://www.buildingforlife.org. Accessed 8/6/2013)

DETR - Department of the Environment, Transport and the Regions. 2000). Urban Design in the Planning System. London, Commission for Architecture and the Built Environment. (Available at http://www.gov.uk/government/publications/urban-design-in-the-planning-system-towards-better-practice. Accessed 8/6/2013)
Evans, A.W. and Hartwich, O. M. 2005. Unaffordable Housing, Fables and Myths. London: Policy Exchange.

HCA - Homes and Communities Agency. 2009. Kickstart Housing Programme, Review of Round One. London, HCA. (Available at http://www.homesandcommunities.co.uk/ public/documents/Kickstart_Round\%20_1_Review.pdf. Accessed 8/6/2013)

Hurst, W. 2010. MPs call HCA to account over Kickstart standards . In Building Design \#1898,8 July, page1.

Samuels, I . 2004. What Homebuyers Want - attitudes and decision making among consumers. London: CABE - Commission for Architecture and the Built Environment.

Samuels, I. 2012. Limits to Localism. In Focus 9, Journal of the CRP-Cal Poly San Luis Obispo, pp. 41-42.

Vandenberg, M. 2013. Teach what our society needs. In Building Design \#2069, 12 July, page 7.

CABE -Commission for Architecture and the Built Environment. 2005. Housing Audit - Assessing the design quality of new homes in the North East, North West and Yorkshire \& Humber. London. (Available at http://webarchive.nationalarchives.gov.uk/20110118095356/http:// www.cabe.org.uk/files/housing-audit-2005.pdf. Accessed $8 / 6 / 2013)$ 
Appendix 1: The final table of a worked example of a Building for Life assessment undertaken by the author.

\section{Building for Life Evaluation}

This is an urban design project which can provide a framework for a development of the highest standards. However at present there is not enough architectural detail for it to achieve a higher rating than that awarded. Its success will depend on the codes which are to be prepared and the rigour with which they are implemented. In particular issues of feasibility (the ambitious range of facilities and the amount of single loaded streets, p151) are of concern.

\section{Upper Redhill}

\section{Criteria}

Environment and community

1 Does the development provide (or is it close to) community facilities, such as a school, parks, play areas, shops, pubs or cafés?

2 Is there an accommodation mix that reflects the needs and aspirations of the local community?

3 Is there a tenure mix that reflects the needs of the local community?

4 Does the development have easy access to public transport?

5 Does the development have any features that reduce its environmental impact?

\section{Character}

\begin{tabular}{|r|l|}
\hline 6 & Is the design specific to the scheme? \\
\hline 7 & Does the scheme exploit existing buildings, landscape or topography? \\
\hline 8 & Does the scheme feel like a place with a distinctive character? \\
\hline 10 & Do the buildings and layout make it easy to find your way around? \\
\hline
\end{tabular}

Streets, parking and pedestrianisation

11 Does the building layout take priority over the streets and car-parking, so that the

Does the building layout take
highways do not dominate?

12 Is the car parking well integrated and situated so as to support the street scene?

13 Are the streets pedestrian, cycle and vehicle friendly?

14 Does the scheme integrate with existing Streets, paths and surrounding development?

15 Are public spaces and pedestrian routes overlooked and do they feel safe?

\begin{tabular}{|l|l|}
\hline & \\
\hline & $\begin{array}{l}\text { Th } \\
\text { no } \\
\text { con } \\
\text { ser } \\
\text { po } \\
\text { som }\end{array}$ \\
\hline A n \\
\hline $\begin{array}{l}\text { Ha } \\
\text { new }\end{array}$ \\
\hline $\begin{array}{l}\text { Pu } \\
\text { prov }\end{array}$ \\
\hline $\begin{array}{l}\text { Gr } \\
\text { pro } \\
\text { spect } \\
\text { etc }\end{array}$ \\
\hline
\end{tabular}
population catchment. There is no management or funding plan for
some of which are expected to be built as a part of the first phase. ew development etc. are discussed but not specified at this stage of the design cannot be answered satisfactorily structure to the development. orientation. Space between buildings shared by different modes development
Ivor Samuels

Environment and

Community Character

Streets Parking and Pedestrianisation

Design and Construction

\begin{tabular}{|l|l|l|}
\hline luation & Evidence & Score \\
\hline
\end{tabular}

There is the intention to provide schools, a local centre and corner shops but the target page 16,74,171

no of dwellings at 3,000 is below that which the Submission CSS ( 4000-6000)

considers to be needed to achieve a sustainable balance of homes, jobs and local

services. More detail is needed on how much support is expected from the existing

mix is proposed although is no indication that this matches local needs

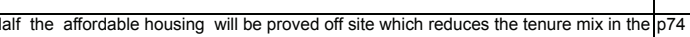

Public transport is intended to be viable but no indication is given as to how it will be

Green infrastructure elements are integrated with landscape features, habitats are protected, solar gain optimised by orientation of dwellings. However no CSH level is number of other schemes and until more detailed designs are produced this question

Existing topography and watercourses have been exploited to form a landscape

Three character areas are defined with different colour, texture and landscape treatments. However, the examples shown are not specific to the site so there is no assurance they would lead to a disitinctive character for either the whole or the parts. Heights of buildings relate to importance of streets; character areas and densities are graded across site from core to edge. Long view corridors are retained to give

The different street types are all defined by the buildings of the perimeter blocks

A range of street types is proposed which fixes building height and set back in relation 13131 to each type ( but see below for reservations on some parking arrangements )

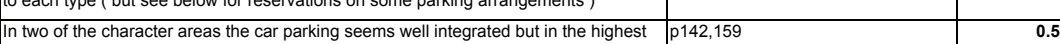
density ( Lower Redhill) the street scene seems dominated by car parking

$\begin{array}{ll}\text { Roads link to existing network south of site but the pedestrian link across a major road } & \mathbf{p} 125,126\end{array}$ is less satisfactory and this is important to ensure a viable local centre in the new

The street types suggest that all would be overlooked by buildings . However at Middle p131, 140 Redhill there are some car parking areas which may not to be overlooked although the level of detail shown makes this difficult to ascertain

Design and Construction

\begin{tabular}{|r|l|}
\hline 16 & $\begin{array}{l}\text { Is public space well designed and does it have suitable management arrangements in } \\
\text { place? }\end{array}$ \\
\hline 17 & Do buildings exhibit architectural quality? \\
\hline 19 & Do internal spaces and layout allow for adaptation, conversion or extension? \\
\hline 20 & $\begin{array}{l}\text { Has the scheme made use of advances in construction or technology that enhance its } \\
\text { performance, quality, and attractiveness? }\end{array}$ \\
\hline
\end{tabular}

The extensive range of open spaces are particularly well designed and it is proposed $1 \mathrm{p} 79-85,155,174$ to set up trust to manage them. Streets are intended for adoption

The types chosen to illustrate the project intentions exhibit quality but there do not yet seem to be rules in place which would guarantee buildings of the same quality in the seem to be rules
design as realised.

no information available 